\title{
Chapter IC \\ Double Exposure in Exile Writing: Khodasevich, Teffi, Bunin, Nabokov
}

his chapter explores the role and semantics of memory in the recol-
lections of native citizens abroad as one of the main topoi in émigré writing. In his Exile in the Narrative Imagination, Michael Seidel's classic definition of an exile as "someone who inhabits one place and remembers or projects the reality of another," points to the dual consciousness of displacement. ${ }^{1}$ We will begin with the "Sorrento Photographs," a poem Vladislav Khodasevich wrote while living in Sorrento in 1925-1926. As an emblematic text of exile memory, this extended meditation on the subject will provide a point of departure for our discussion. The poem opens with the accidental "double exposure" of a forgotten old negative and segues into a projection of images of Russian cities onto sites along the Amalfi coast.

The brilliant device of "double exposure" would become indispensable in contemporary prose, where it was used to situate the exile in history, revealing hidden relations between memory of the past and the actual present. This device prompted recollections of Russian cities of the exiles' past as experienced in the European metropolitan centers, enabling writers to reflect on the inherent tensions of the diasporic condition, with its dual consciousness of place and time. These reflections center on vagaries of émigré memories of cities in Nadezhda Teffi's microcosm of Russian Paris, Bunin's Franco-Russian Paris, and Nabokov's Russian Berlin. Teffi's satirical stories present characters rooted in the past—beset by nostalgia, they remain profoundly alienated from the City of Light. Bunin's exceptional late story, "Paris," captures the subtle ways

1 M. Seidel, Exile and the Narrative Imagination (New Haven and London: Yale University Press, 1986), ix. Seidel cites this definition from a study of the history of exile, funded by the United Nations: Paul Tabori, The Anatomy of Exile: A Semantic and Historical Study (London: Harrap, 1972). 
that enabled the émigrés to dwell in both the Russian and French Paris, and in two languages, as Russians. The young Nabokov/Sirin, writing in Berlin, is striking for his stance against nostalgia, choosing creative modes of exile memory that participate in European modernity and literary modernism.

\section{Khodasevich}

In Khodasevich's poem "Sorrento Photographs," memory is revealed through the "double exposure" of Moscow and Petersburg onto the site of the classical world. Indeed, fascination with memory goes back to ancient Greece, where manuals on the "theater of memory" or Mnemosyne underscored the importance of remembering cities and their architecture. The treatises emphasized the visual sense of sight as the strongest, with memory trained on the recollection of specific architectural detail. ${ }^{2}$ This was considered especially important when the site was lost in an earthquake or wartime. In the

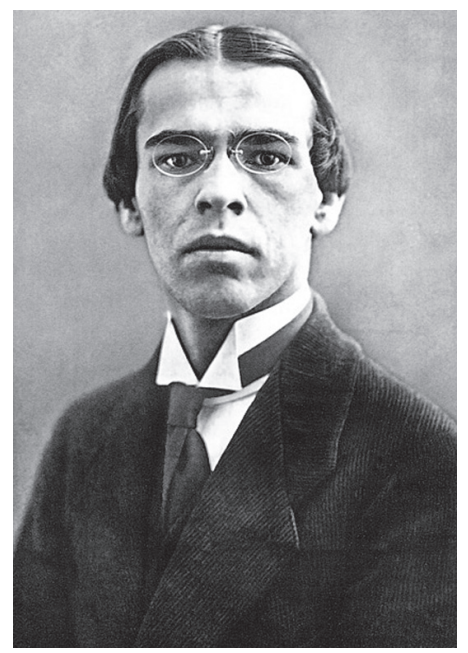

Vladislav Felitsianovich

Khodasevich, 1886-1939 Jewish tradition, the destruction of the temple, followed by exile, resulted in devotion to Jerusalem as the sacred city, memorialized in prayer and poetry. This sustained the scattered Jews in their millennial longing in the diaspora. In Booking Passage, Sidra de Koven Ezrahi reminds us that Psalm 137 generates the poetic vocabulary of exile: "If I forget thee, O Jerusalem, let my right hand forget its cunning, let my tongue cleave to my palate ..."3 Following these ancient models, we will observe how memory of the lost homeland, focused on its two cities, Moscow and Petersburg, shaped Russian diasporic literature in the struggle for cultural and national continuity, declared as the diaspora's sacred mission.

2 F. A. Yates, The Art of Memory (London and New York: Routledge, 1999), 4.

3 Sidra DeKoven Ezrahi, Booking Passage: Exile and Homecoming in the Modern Jewish Imagination (Berkeley, Los Angeles, London: University of California Press, 2000), 9. 
Writing in 1925-1926, Khodasevich appears cognizant of the complex structure of layers of memory, of its rich symbolism, but also of its unreliability. He opens "Sorrento Photographs" with an accidental and whimsical "double exposure" of a forgotten old negative of a goat whose horns are "butting Vesuvius." This incongruous dream-like image (familiar from the commedia dellarte tradition of the goat-cuckold) emerges from beneath the film of the lush Italian landscape of the Amalfi coast. By analogy, the forgotten negative leads to a superimposed recollection of two key images of Moscow and St. Petersburg. Khodasevich creates an imaginative context for an instance of involuntary visual memory that reveals the implications of the historical trauma of the Revolution. The poem represents an exception in his cycle, European Night (1926-1927), imbued with acute alienation in the modern European metropolis, Berlin and Paris, where the impoverished poet wanders, struggling with the possible loss of poetic voice in the dark angst of exile. ${ }^{4}$ These cities and the life they offer appear grotesque to the eye of the poet-observer, captive in his claustrophobic exile condition. This acute sense of alienation, however, is absent from "Sorrento Photographs." Situated in the classical world, this poem has a humorous opening, where a "scatterbrained" photographer's inadvertent and mischievous "double-exposure" changes the mood, prompting the exile's free imaginative meditation on memory and history.

Indeed, the photographer's chance "forgetfulness" of the old negative triggers two specific visual memories of native Russia in stereoscopic images. Note that the speaker's memory, as involuntary as it is highly symbolic, offers precise recollections of cultural, topographic, and architectural detail in both instances. First, projected onto the Amalfi Pass is a vision of a "dilapidated house" in a humble quarter of Moscow during the funeral of a janitor, Saveliev, whose plain pine coffin is being carried out of a basement to the sound of a traditional women's lament. From the memory of an Orthodox funeral in Moscow, the city of medieval churches, the narrative switches to the present in a description of a Catholic religious procession in Sorrento at dawn on Good Friday, when an effigy of the Virgin is carried into the cathedral. As the lyri-

4 For a brilliant analysis and translation of the poem, see David M. Bethea, Khodasevich: His Life and Art, 300-316. 
cal "I" of the observer continues on a motorcycle ride along the sinuous coastline, with Naples and Mount Vesuvius rising out of the fog, there is a vision of Petersburg-an upside-down reflection in the Bay of Naples of the angel atop the Peter and Paul Cathedral, an ironic architectural detail of this massive, forbidding site of imperial power, now a symbol of its past glory and fall. The two Russian "double-exposures" connect the two cities of Moscow and Petersburg and symbolically convey the sense of exile as death after the fall of the empire, succeeded by a secular Soviet state.

In David Bethea's acute observation, the narrative sequence works so as "to foreshorten the 'distant' viewpoint of these two memories as the 'nearer,' more recent, viewpoint of the third memory is sandwiched inbetween, describing a Roman Catholic procession..." The complex juxtapositions of the "nearer" and "distant" memories-of the Orthodox and Catholic rituals of death and resurrection, and of Petersburg as a recent necropolis with the historic "Pompeian horror" as background-inform the observer's perspective. Indeed, they encapsulate the radical historical event of the Revolution within the greater time of ancient and Christian historiography. ${ }^{6}$

The poem offers striking insight into the complex processes of memory and its role in history. After the sober images of Russia projected onto the site of the Amalfi coast, the moment of levity, found in the initial image of the negative of the "mischievous photographer," returns as the poem ends on a light note, with acute observations on memory as capricious, akin to dreams and "probably just as false." Despite the justified skepticism concerning memory's validity, corroborated by Freud who deemed that "memories are in themselves unconscious. They can be made conscious ...," the speaker nevertheless appreciates the invaluable insight they offer.7 The release of "involuntary" memory of the two cities, with their traditional association of church and Empire, has an important function. Through its imaginative therapeutic reworking, memory enables the poet to look toward the future without apprehension. The poem

Ibid., 30 .

6 I am indebted to Hayden White for this suggestion.

7 S. Freud, Interpretation of Dreams, trans. James Strachey (New York: Avon Books, 1965), 578. 
concludes with a surprisingly open-ended visionary question: "and what will overlay in turn/ the shadow of Sorrento photographs?"

What makes this optimistic question possible and how does it inform the representation of exile, memory, and imagination? The sublime landscape of the classical world, the scene of empires past and of a deadly volcanic eruption, enable the poet to move beyond the exile's nostalgia or angst to encompass a greater sense of history and to imagine its continuity, rather than the paralysis of rupture. This move also allows a singularly positive sense of modernity to emerge, away from the oppressive grotesque of the urban metropolis of Berlin and Paris in the rest of the European Night cycle. The two symbols of modernity-the camera that executes the "double-exposure," along with the motorcycle conveying the "I" along the coast-are instrumental in creating the "distant" and the "nearer" perspective, enabling the "involuntary" memory to emerge.

\section{Contemporary Prose}

While the visionary poem of Khodasevich offers remarkable insight into the workings of exile memory, with the clear parameters of its temporal and spatial relations, the poet's understanding of the vagaries of memory and the broad historical perspective remain exceptional in the literature of the first decades of Russia Abroad. Our discussion of émigré prose will follow how the semantics of "double exposure" as a device, featured by Khodasevich, shapes the narrative strategies of writing on exilic recollection, focusing on the role of native cities in foreign settings. This will allow us to observe how different projections of the past onto the present affect the dynamics of diasporic "accommodation with, as well as resistance to, host countries and their norms."

The stories differ from this exceptional poem - they resemble the rest of the European Night cycle, with their emphases on the pain of exile, encumbered by memories of the past. The stories point to several phenomena affected by this condition. They focus on problems of bilocality and dislocation, revealing what Doris Sommer dubs as the exile's "split con-

8 J. Clifford, Routes: Travel and Translation in the Late Twentieth Century (Cambridge, MA: Harvard University Press, 1997), 251. 
sciousness," inherently tied to "grammar trouble." We will consider how both bilocality and bilingualism contribute to the workings of memory in the difficult process of "accommodation," which involves translation of the foreign cultural context into familiar terms. Writers depict Russian characters in European cities as they contend with the spatial and cultural alienation of everyday reality. But instead of the broader historic meditation found in "Sorrento Photographs," with the careful balance between the "near" and "distant" perspective, the stories evoke vivid images of the distant familiar past that threaten to disrupt and even submerge the present of the Paris or Berlin settings.

Unlike the speaker in "Sorrento Photographs," who is firmly planted in the landscape of the Amalfi coast and imagines a greater historical perspective that enables him to contextualize his country's predicament, most of his Russian contemporaries are caught in up in the struggle with the constant challenges of everyday life in foreign cities. Events of the recent past and a sense of dislocation in the uncertain present contribute to the exile's "resistance" to the new places of residence, exacerbated by the inhospitable conditions in the host countries. Moreover, once in Europe after 1917, Russian émigrés suffered a double-estrangement-a loss not only of the Russian, but also of the European home as they knew it during earlier travels and study abroad. This reinforced "resistance" rendered accommodation all the more difficult. As mentioned earlier, Khodasevich conveys painful alienation in the European Night cycle. Andrei Bely experienced this difference acutely. As Aleksandr Lavrov states in his essay "The Two Germanies of Andrei Bely" (Dve Germanii Andreia Belogo), the earlier connection with German culture and writers, especially Schopenhauer and Nietzsche, was as formative for Bely as was Russian culture. ${ }^{10}$ Thus, during his 1905-1906 trip abroad, Bely described his fascination with Munich, an artistic and cultural center, finding that "every German is a bit of a genius, when he drinks beer and smokes a pipe ..."11 As Lavrov demonstrates, the contrast with Bely's experience fifteen years later,

9 D. Sommer, “Introduction," in Bilingual Games. Some Literary Investigations (New York: Palgrave MacMillan, 2003), 7.

10 A. Lavrov, “Dve Germanii Andreiia Belogo," Europa Orientalis 22:2 (2003): 39. See also "Strana geniev" in Deutsche und Deutschland aus russischer Sicht, ed. L. Kopelev (Munich: Wilhelm Fink Verlag, 2006). The same was true for Vassily Kandinsky.

11 Lavrov, "Dve Germanii Andreiia Belogo," 43. 
during his stay in Russian Berlin (1921-1923), was all the more striking then, when the city had become but a stage for a display of his personal crisis and the angst of temporary exile. ${ }^{12}$ Another contemporary living in Berlin, the philosopher Fedor Stepun, who had studied philosophy in Heidelberg as a youth, writing in his 1923 essay "Thoughts of Russia" (Mysli o Rossii), was strikingly explicit about his return to an unwelcoming Europe, indifferent to the Russian experience: "exile to Europe for us turned out to be an exile from Europe."13

To combat their sense of displacement, the émigrés hastened to create the lieux de mémoire that had become indispensable "because there are no longer the milieu de mémoire, settings in which memory is a real part of everyday experience." ${ }^{14}$ One way to achieve this was through a recreation of Russian enclaves in foreign cities to provide an illusion of familiarity and to allow an unhampered use of the native language as a way to counteract loss. ${ }^{15}$ As the stories demonstrate, these émigré "micro-archipelagos" of identity offered the necessary "stable structure of social relations informed by the material articulation of the national spirit." 16 Hence the use of such toponyms as Russian Paris or Russian Berlin indicated that they were not identical with the French or German capitals. Moreover, the Russian toponyms rendered the actual Paris or Berlin alien in the émigré psyche. As late as his last American novel, Look at the Harlequins! (1974), Nabokov recalls Russians living in interwar Berlin and Paris, where the hero refers to the émigré section of the city as "Passy na Rusi." [Passy-on-the Russian-Riverbanks] ${ }^{17}$ This was the area of Russian nursery schools and cafes, bookstores and publishers. Émigré stories take place in Russian neighborhoods transplanted by memory, which provide ample evidence of the domestication of foreign

12 Ibid., 41-42.

13 F. Stepun, "Mysli o Rossii," Sovremennye zapiski 17 (1923): 351-352.

14 Pierre Nora, "General Introduction: Between Memory and History" in Realms of Memory: Rethinking the French Past, under the direction of Pierre Nora, translated by Arthur Goldhammer, vol. 1 (New York: Columbia University Press, 1996), 1.

15 K. Solivetti, M. Paolini, "Paradigmy 'izgnaniia' i 'poslannichestva': Evropeiskii opyt russkoi emigratsii v 20-e gody” in Europa Orientalis 22:2 (2003): 145-170. I would like to thank A. Shishkin for this reference.

16 Ibid., 169.

17 V. Nabokov, Look at the Harlequins! (New York: McGraw-Hill, 1974; reprinted, Vintage Books, 1990), 87. 
urban space through the superimposition of the familiar on the foreign, a variant form of "double exposure" of the past on the present, essential in mapping the urban toponymics of exile.

\section{Teffi}

There was no better ethnographer of Russian Paris than Nadezhda Teffi, whose satirical stories provided a complex and witty depiction of émigré existence as she diagnosed both the symptoms and dangers of exile memory. Presented as "involuntary" in "Sorrento Photographs," memory and the superimposition of the past on the present are shown to be willful and obsessive in her characters, beset by nostalgia or "longing." As Svetlana

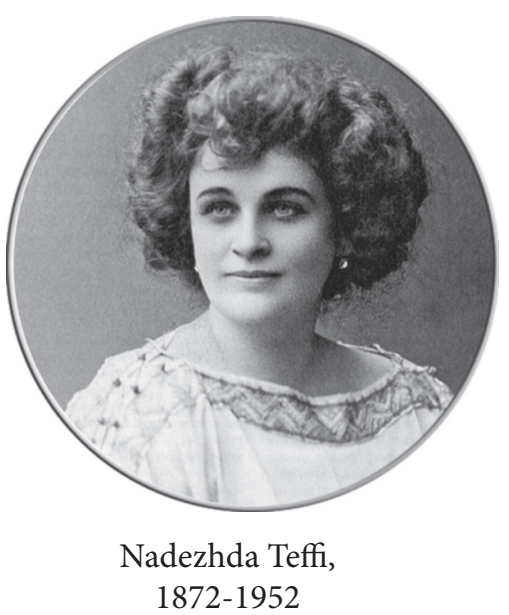
Boym has shown, the typology of nostalgia ranges from a "restorative" to a destructive state, akin to illness. ${ }^{18}$ In Teffi's Paris it is the latter, with the "familiar" or the "preserved" Russian culture carried as part of émigré luggage. This coexists with the "alien" aspects of the land of residence, confounding the "near" and "distant" perspective of the hapless protagonists, so that the latter appears more real than the immediate context, which is almost obliterated. The condition of nostalgia is often confounded with memory and endangers life.

The exile's ubiquitous longing, along with the daily confusion of existence dominated by displacement, are the central themes of Teffi's tales. Using bilingualism as a symptom of "split consciousness" of Russians in Paris, Teffi creates a gallery of characters who contrive to keep up a semblance of native "byt." Her stories are populated by Russian cabbies, seamstresses, milliners, shopkeepers, hairdressers, and poor teachers. She subjects the émigrés, whose memory dwells in the homeland and dominates consciousness, to an ironic examination. The title story of the collection, Nostalgia, dissects this condition, defined as a "disease,"

18 S. Boym, The Future of Nostalgia, 41. 
whose victims turn passive and "do not believe in anything, do not expect anything, do not want anything. They died." 19 They are more interested in the news from "there" than "here." These people even transpose the stock landscape of the homeland to Paris, and to the detriment of their immediate surroundings: "their l'herbe [grass] is not our travka-muravka [Russian "grass" with a folksy rhyme-G. N. S.]; their trees may be very nice, but foreign; they do not understand Russian." ${ }^{20}$

Language is key as Teffi stakes out an essentialist monolingual position taken to an extreme: "You cannot translate a Russian soul into French ..." (Perevedite russkuiu dushu na frantsuzskii iazyk ...). ${ }^{21}$ The absurdity of this exclusive position of cultural nationalism, where the past outweighs the present, is evident in the story titled "The Dacha Season" (Dachnyi sezon). It conveys geographic displacement in the opening statement, where the oral intonation of skaz, reminiscent of Zoshchenko, expresses an opinion of the collective reader: "In Paris we observe a phenomenon that is strange to us foreigners - there are no seasons in Paris" (V Parizhe net prirodnykh sezonov). ${ }^{22}$ This condition is underscored when the categorical statement is paraphrased with an emphatic intonation as if of a logical outcome: "There are no natural seasons" (sezonov prirodnykh net). ${ }^{23}$ By contrast, the four Russian seasons, along with their requisite items of clothing, are perceived as part of natural order of things, while in Paris "all is upside down" and "straw hats are worn in February."

In her critique of the émigré rejection of the "present" in "resistance" to exile, Teffi is aware of the dangers inherent in the totalizing anxiety of loss. The story "Raw Material" (Syr'e) comments on such opinions of her compatriots that bemoan the futility of transporting the trappings of Russian culture to Paris, where "a Great Sadness" (Velikaia Pechal') is ever-present. The fear of losing cultural memory deepens the sadness: "Even Tolstoy and Dostoevsky ... are remembered more and

19 N. Teffi, Nostal'giia. Rasskazy, vospominaniia (Leningrad: Khudozhestvennaia literatura, 1989), 161. The collection represents stories from different periods. Quotations in the text refer to this edition (translations are mine-G. N. S.).

20 Ibid., 162.

21 Ibid.

22 Ibid., 164.

23 Ibid.

24 Ibid. 
more rarely." 25 They have become irrelevant in this existence "beyond the grave," ${ }^{26}$ hence the anxiety that Russian literature will be forgotten. This negative argument extends to émigré writers and when one of them remembers that he was once an author, the response is: "How can one write? Our way of life is dead" (nash byt umer). ${ }^{27}$ Teffi's irony recalls the curse of the Soviet critic, Voronskii, that writers in exile would face artistic sterility and death; she responds with irony to both Soviet and émigré critics, combating such statements of extreme negativity in an attempt to restore the exiles' shattered sense of identity and chart the creative possibilities of memory.

Teffi's wittiest and most poignant expression of "foreignness" and dislocation in the famous story "Ke fer?" belongs to a former Russian general who finds himself stranded in the midst of ceaseless traffic in the Place de la Concorde, the heartbeat of Europe. As he looks around at the "sky, the square, the houses, and the gaudy, chatty crowd," the full force of the drama of his schizoid existence and confusion explodes in the exasperated, brilliantly amalgamated bilingual question "Ke fer? Fer-to $k e$ ?" Teffi adds the flourish of a Russian particle -to to the French colloquial translation of "what's to be done?" (chto delat'?), a witty paraphrase of one of Russia's "accursed questions" and the title of Chernyshevsky's famous socialist utopian novel, considered the predecessor of the October Revolution. Thus the bilingual pun of the story's title brilliantly grasps the linguistically-manifested split consciousness: it reveals both the general's dislocation and the irony of history, of which he is supremely unaware.

In her exploration of the predicament of exile, of the uses and misuses of memory in a "split consciousness," Teffi demonstrates the dangers of excessive dwelling in the past, when "resistance" exceeds "accommodation." Concerned with the challenge of the exile condition, the vagaries of memory, and with the continuity of the literary tradition, Teffi treats the themes of longing and dislocation without sentimentality. Her irony and the masterful use of bilingualism is a medium for representing the cultural clash through interlingual punning, pidgin Russian and Russified

25 Ibid., 167.

26 Ibid., 168.

27 Loc. Cit. 
French, which connects her work with that of her contemporary, Ivan Bunin, as well as with her younger compatriot, Vladimir Nabokov.

\section{Bunin}

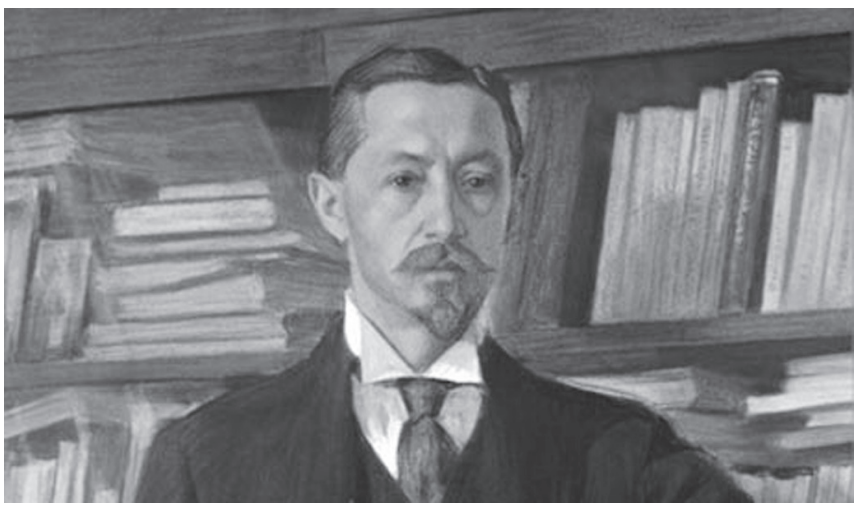

Ivan Alekseevich Bunin, 1870-1953

In contrast to Teffi's stories, Bunin's "Paris" (1940), written at the end of the historical period of the First Wave emigration, presents a striking departure. It examines the simultaneous practices of both "resistance" and "accommodation" in their interaction. ${ }^{28}$ In this way it can be seen as a transitional text between the visionary "Sorrento Photographs" and Teffi's exclusively Russian Paris. This story is as exceptional in Bunin's émigré period as "Sorrento Photographs" was in the European Night of Khodasevich. It is part of the collection Dark Alleys (Temnye Allei), which Bunin wrote toward the end of his remarkably creative life, during and after World War II. Most of the stories, set in Russia just before or on the eve of the Revolution, provide stunning descriptions of native settings in poignantly tragic tales of love. "Paris," however, is a story of requited love, uncommon for the writer. The story adds to the extraordinary "grammar of love" in his oeuvre. By incorporating bilingual code-switching, Bunin carefully placed his two characters on the borderlines of French and Russian Paris, using exile toponymics as a test study of split consciousness and bilingualism.

28 I. Bunin, "Parizh," Temnye Allei. Sochineniia v trekh tomakh, v. III (Moscow: Khudozhestvennaia literatura, 1982). Quotations from the text refer to this edition (translations are mine. -G. N. S.). 
The man and the woman in the story are Russian émigrés who remain nameless and are referred to in the gender-marked third person pronoun. They dwell quite ably in two languages and in two toponyms, Russian and French Paris, whose geography is precisely mapped out. They meet on a wet night in late fall in a small Russian restaurant in the Russian Passy neighborhood, where she works as a waitress. When she addresses him in French, he is taken aback and immediately wants to ascertain that she is Russian. As she explains, she speaks French because of Parisian customers who frequent the restaurant. He, in turn, describes himself as "an old Parisian" and his French is replete with proverbs he learned while living in Provence. As he resorts to them at certain moments in their conversation, it becomes clear that these are mostly misogynist commonplaces, which serve as a superficial layer in emotional and cultural adaptation, what Sommer calls a "bilingual prosthesis." 29

After three encounters, they have a date for a night out on the city. Bunin is careful in providing specific street and metro directions to orient the reader as the two protagonists cross the sections of the city that, like the two languages, remain distinct and separate in their consciousness. The first part of the evening is spent in the center of French Paris, at a cinema near the Étoile. The cinema, a site of modernity, plays its part; the action film on the screen with a Chaplin look-alike does not interest the couple, but they become "connected by intimacy" in the dark auditorium, which allows their conversation and acquaintance to continue. Not surprisingly, however, they are both bored with the film and agree to leave. They go across town to Montparnasse, to the favorite Russian gathering place, the café La Coupole, where they have a sumptuous dinner. The specific urban mapping is significant in the swift development of their attachment, since the night ends in his apartment in Russian Paris. Their emotional understanding is admirably direct as they become lovers and decide to move in together. The story's narrative is composed of three parts, following nature and calendar cycles: it begins in the fall, continues through the winter and up to Easter, when he suddenly dies of a heart attack. This structure parallels the underlying significance of exile as the ultimate separation or death, allowing only an intermittent resurrection in their meeting and love.

29 Doris Sommer, ed., Bilingual Games, 8. 
The city is central in Bunin's masterful story, as it demonstrates how "the split of language and being" enables the characters to function in everyday life. ${ }^{30}$ Their grasp of French, however, is superficial, a conscious gesture of "accommodation" to foreign culture that serves them well in protecting the deep repository of quintessentially Russian traits that reveal emotional directness and capacity for intimacy. As they exchange their pre-history in brief remarks, it is understood as part of the larger émigré history, with commonly recognizable components and references that include the Civil War and stages of exile, beginning in Istanbul. Although a possibility of happiness exists in Bunin's pre-war Paris, it is tenuous and tragically short-lived. Despite the protagonists' conscious accommodation to their Parisian existence, it remains secondary to their Russian past, which dominates the present. The two toponyms-Russian and French Paris-remain safely distinct in their consciousness.

\section{Nabokov}

The younger writer Vladimir Nabokov took up the challenge of finding a way out of the self-enclosed exile universe. Although memory was central in his work, Nabokov disparaged the banality of nostalgia and the émigré "resistance" to the reality of life in European cities. While his early work was replete with evocations of beloved Russia, he was as ironic about the émigré insistence on dwelling in the past as was Teffi. Aware as he was of the tension in exile toponymics, Nabokov's predilection for the modern metropolis of Berlin set him apart from his compatriots, who clung to the Russian enclaves and disparaged modernity.

His last Russian novel, Dar (The Gift) (1937), situated in Berlin, provides a very careful mapping of its German and Russian sections. The novel's hero, a young writer Fedor, is interested in the coexistence of the two Berlins and he is closer to the speaker of "Sorrento Photographs" in his awareness of juxtaposing the "distant" and "near" perspectives, seeking to retain the temporal relationship between them. While walking or riding the bus, Fedor partakes of the entire city, with an acute awareness of its sites and the visual pleasures they offer. Fedor notes "a multitude of streets diverging in all directions ... and skirting the above-mentioned

30 Ibid., 7. 
places of prayer and refreshment ...," noting "to the right ... the gates of a tram depot with three beautiful birches standing out against its cement background ...."31 Nabokov is careful to mark the invisible border separating the two Berlins: "Crossing Wittenberg Square, where, as in a color film (kak v tsvetnom kinematografe), roses were quivering in the breeze around an antique flight of stairs that lead down to an underground station ...."32 As the narrator approaches Russian Berlin, we note that the camera of "Sorrento Photographs"

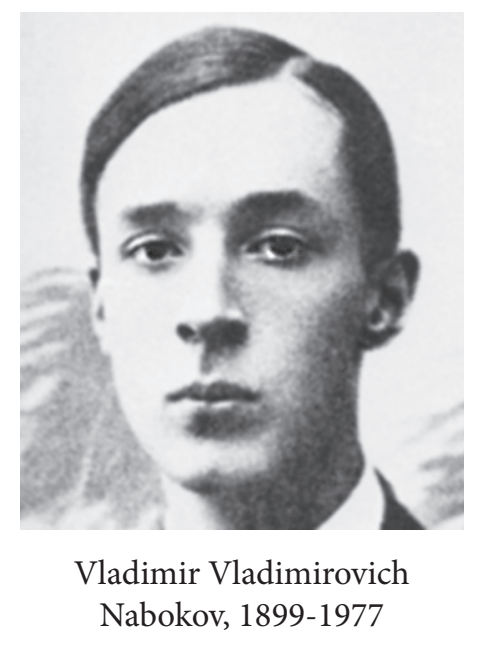
is now replaced by a movie camera, serving his minute observation of the local scene, its ubiquitous characters, and their habits: "As always happened when he came to this street, ... he met an elderly, morbidly embittered St. Petersburg writer...."33 The rest of the chapter is devoted to the internal discourse of the tightly knit émigré literary community of Russian Paris and Berlin, in which prominent literary personalities and their respective positions are mentioned and discussed with either irony or admiration. The latter attitude is reserved for Khodasevich, whom Nabokov considered the greatest émigré poet.

Acutely aware of the "double exposure" syndrome, Nabokov knows how involuntary memory functions, so that the distance between points in the "near" Berlin is automatically transposed into the "distant" Petersburg or Moscow. Thus, when Fedor moves from the old apartment to new lodgings where he will meet his beloved and become a writer, memory plays its part in his calculations: "The distance from the old residence to the new was about the same as, somewhere in Russia, that from Pushkin Avenue to Gogol Street." ${ }^{34}$ We note the ironic general designation "somewhere in Russia," which generalizes the compulsive act of memory, though it remains highly symbolic.

31 V. Nabokov, The Gift (New York: Capricorn Books, 1970), 173.

32 Ibid., 178.

33 Ibid.

34 Ibid., 157. 
Playing with the exile toponymics and the "distant" and "near" perspective, Nabokov renders the foreign setting of the present as self-consciously irrelevant. Thus he graphically demonstrates how the nostalgic illusion of living in the past functions in Russian Berlin: “... so that it seemed as if on this German street there had encroached the vagabond phantom of a Russian boulevard" (bluzhdal prizrak russkogo bul'vara ...). ${ }^{35}$ In a move reminiscent of the "mischievous photographer" of "Sorrento Photographs," Nabokov explores the device of double-exposure in the spectral phantasm of a remembered Russian cityscape. Manipulating the "distant" and "near" possibilities of the camera perspective, he goes a step further and reverses the superimposition. He imagines a street in Russia "with several natives taking the air, swarmed with the pale ghosts of innumerable foreigners flickering among those natives like a familiar and barely noticeable hallucination." ${ }^{36}$ This device of reversal will be used many years later in Nabokov's Speak, Memory, where he conveys a typical émigré attitude towards the "spectral Germans and Frenchmen in whose more or less illusory cities we, émigrés, happen to dwell." ${ }^{37}$ The ability to change the spatial and temporal perspective, proffered by Khodasevich, becomes an indispensable instrument of the writer's craft in Nabokov's ironic take on the workings of memory: it allows his hero to distinguish between appearance and reality, between the past and the present.

Most importantly, however, this ability has great implications for the writer's craft. It allows Nabokov to transpose involuntary memory into the creative sphere of the imagination when his narrator, Fedor, declares himself to be a "seeker of verbal adventures" (ved' ia-to sam lish' iskatel' slovesnykh prikliuchenii), thus defining his priorities. ${ }^{38}$ As a writer, Fedor is also acutely aware of the tensions inherent in dual consciousness and bilingualism. While riding a city bus, he notes another local urban site that instantly contrasts with a great city of his past: "along the toothpaste advertisement upon it swashed the tips of soft maple twigs-and it would have been pleasant to look down from above on the gliding street

\footnotetext{
35 Ibid., 178.

36 Ibid., 178.

37 Speak, Memory. An Autobiography Revisited (New York: Vintage International, 1989), 276.

38 Nabokov, The Gift, 157.
} 
ennobled by perspective ...." ${ }^{39}$ However, Fedor's mind wanders inward to the contradictions of his émigré existence and the meager living he makes by tutoring English: “... rushing from lesson to lesson, wasting his youth on a boring and empty task, on the mediocre teaching of foreign languages-when he has his own language, out of which he can make anything he likes ..." He comes to realize that the city, foreign or remembered, along with his native language, constitute the potential tools of his craft.

At some point Fedor reiterates Teffi's proverbial "Que faire" question and in his answer assigns a specific place to the ever-present memory of the homeland: “ ... and 'what to do now?' Ought one not to reject any longing for one's homeland, for any homeland besides that which is with me, within me, which is stuck like the silver sand of the sea to the skin of my soles, lives in my eyes, my blood, gives depth and distance to the background of life's every hope?"40 And while Fedor proclaims internalized memory to be an indelible part of his being, he also understands its role: it creates a precious perspective of "depth and distance" in any subsequent life experience. He is also supremely aware that involuntary memory is always there, ready to surface at any moment: "Someday, interrupting my writing, I will look through the window and see a Russian autumn."41

The device of the double exposure, discovered by Khodasevich a decade earlier, is now a part of the writer's arsenal. In his creative exploration of the device and imaginative potential of cities in the late 1930s, Nabokov creates an evolving typology of memory. While marking stages in the evolution of his exile consciousness, Fedor detects a significant change from the acute, almost physiological longing of earlier recollections: "Gradually, as a result of all these raids on the past of Russian thought, he developed a new yearning for Russia that was less physical than before ...."42 This corresponds to the Russian version, but not in an exact translation, which would read "... gradually, ... he developed a new, a less landscape-rooted longing for Russia" (Postepenno ... v nem

\footnotetext{
39 Ibid., 175.

40 Ibid., 187.

41 Ibid., 187.

42 Ibid., 215-216.
} 
razvivalas' novaia, menee peizazhnaia, chem ran'she, toska po Rossii...). ${ }^{43}$ This significant instance of an inexact translation serves a purpose: It designates the proper place of memory both in Nabokov's evolution as a bilingual writer and in the history of émigré culture. It is interesting that the English translation of this passage omits the epithet "peizazhnaia" in describing the stock visual image of nostalgia. Ironically, even Nabokov, who was involved in preparing the English version of the novel, must have thought the term and its semantic associations untranslatable! Nabokov's novel stands in sharp contrast to the uncritical and obsessive recollections of the past of the émigré community that Teffi satirized in her stories.

The poetics of exile memory of native cities reaches its apogee in Nabokov's remarkable story "The Visit to the Museum" (Poseshchenie muzeia, 1938), which concludes more than a decade-old history of double exposure. ${ }^{44}$ In Nabokov's Russian period there was always a clear realization that there is no return home. The first person character of the story, a Russian émigré residing in Paris, plans a trip to a French provincial city, when his friend, a fellow émigré, asks him to find a painting by a French painter, once belonging to his grandfather. It is purported to be hanging in the local museum and he is to purchase it back, if possible. During the planned visit to the museum, where the painting is actually found, the narrative takes an unexpected turn. Nabokov uses the device of the "dream" when the hero is "transported" back to Russia, but the familiar pavement and streets of his native Petersburg do not provide the reassurance of "restorative nostalgia." Instead, the narrator experiences extreme dislocation, since the beloved old sites have been transformed into "a factual Russia of today, forbidden to me, hopelessly slavish, and hopelessly my own native land." ${ }^{45}$ As in "Sorrento Photographs," the old Petersburg no longer exists. The story of reverse estrangement in the once familiar city underscores an important discovery, made earlier by Fedor

43 V. Nabokov (V. Sirin), Dar, in Sobranie sochinenii russkogo perioda v piati tomakh, vol. 4 (St. Petersburg: Simpozium, 2000), 384.

44 "Poseshchenie muzeia" was first published in Sovremennye zapiski, LXVIII (Paris, 1939). It was included in a collection Vesna v Fial'te (New York, 1959). English translation: V. Nabokov, "Visit to the Museum," in The Stories of Vladimir Nabokov (New York: Alfred A. Knopf, 1995), 281. 
in The Gift, that memory is indeed distinct from reality-the recreation of the past can occur only in the imagination. Nabokov captures the creative potential of memory as a trope in the evolution of exile literature.

Moreover, as the memory of prerevolutionary Petersburg comes to grips with the Soviet Leningrad fantastic, the story presents what Maxim Shrayer aptly dubbed "the paradox of recognition." ${ }^{6}$ The alienation now stems not from Paris or Berlin, but from the internalized memory of the beloved native city, which has no counterpart in its irrevocable transformation in historical reality. The ending is succinct, as the narrator somehow manages to return abroad from the long dream sequence, swearing that he would never again attempt to fulfill "commissions entrusted one by the insanity of others," that is, by the Russian émigré burdened with nostalgia.

This story of the imaginary journey from Paris back to Petersburg has important implications for the evolution of the First Wave of émigré literature at the end of two decades of its history. "The Visit to the Museum" has great bearing on the 1930s diasporic debates concerning the writer's responsibility to the classical tradition in the context of the émigré mission, dedicated to its continuity. According to Aleksandr Dolinin, the story is also significant as a "meta-reflection on the Petersburg myth." ${ }^{77}$ The rich nineteenth-century tradition reaches its conclusion here: like the grandfather's portrait, it now belongs in the museum of literary history. Nabokov's story marks not only the limits of nostalgia and memory as it assigns them to the imaginary sphere, but it also seeks a broader perspective that opens new creative venues for an émigré writer in the context of European modernism.

\section{Conclusion}

The centrality of cities in émigré writing is tied to their dynamic role in exile memory. The poem and prose considered here provide ample evidence that Russian writers living abroad defied Voronskii's curse of "death and sterility." Their work demonstrates that a creative use of vi-

46 M. D. Shrayer, The World of Nabokov Stories (Austin, TX: University of Texas Press, 1999), 62.

47 A. Dolinin, Istinnaia zhizn' pisatelia Sirina. Raboty o Nabokove (St. Petersburg: Akademicheskii Proekt, 2004), 356. 
sual memory of native cities recalled in the European metropolis allowed their writing to participate in both the continuity and the evolution of the national literary tradition. The "double-exposure" syndrome in exile imagination reveals a complex chronotope of disparate histories, of simultaneous dwelling in dual temporalities and languages. Prerevolutionary Moscow and Petersburg find their counterparts in Naples and Sorrento, or in Paris and Berlin. Following Khodasevich, writers tapped the creative potential in the play of double exposure to connote the extreme dislocation of exile and the rich vein of visual and linguistic memory. Khodasevich's contemporaries, Teffi and Bunin, depicted life in Russian Paris, exploring the possibilities for a future life in the diaspora. Nabokov realized the full creative potential of memory and the dynamic importance of cities, turning dislocation and bilingualism to his advantage. More than that, Nabokov accomplished something that was not possible in his native land at the time-he moved beyond the traditional literary mythologies of St. Petersburg. His work continued the experiments of prerevolutionary Russian modernism and participated in a European modernism where cities and memory play a central role, thus contributing to the rich twentieth-century tradition of exile writing. 